\title{
Kualitas Spermatozoa Tikus Jantan yang Diberi Tepung Kedelai Kaya Isoflavon
}

\author{
Sussi Astuti \\ Jurusan Teknologi Hasil Pertanian, \\ Fakultas Pertanian Universitas Lampung,Bandar Lampung
}

\begin{abstract}
Abstrak
Spesies oksigen reaktif (ROS) adalah radikal bebas yang berperan penting pada beberapa proses fisiologis spermatozoa. Spermatozoa membutuhkan ROS pada level rendah untuk menginduksi proses tersebut sehingga fertilisasi dapat berlangsung. Komponen bioaktif isoflavon yang terkandung dalam kedelai berperan sebagai penangkap radikal bebas, menghambat pembentukan peroksida lipid, serta mencegah kondisi stres oksidatif pada jaringan yang memproduksi spermatozoa. Dua puluh lima ekor tikus jantan strain Sprague Dawley umur 21 hari dibagi dalam lima kelompok dan mendapat perlakuan tepung kedelai kaya isoflavon secara oral dengan berbagai tingkatan dosis isoflavon selama dua bulan. Tikus betina strain Sprague Dawley umur 21 hari digunakan untuk mengobservasi fertilitas tikus jantan. Ransum basal kasein tikus jantan dan betina disusun isonitrogen dan isokalori dengan kadar protein 10\%. Angka konsepsi dan jumlah fetus dievaluasi pada tikus betina yang dikawinkan dengan tikus jantan. Hasil penelitian menunjukkan bahwa pemberian tepung kedelai kaya isoflavon pada berbagai tingkatan dosis tidak berpengaruh terhadap abnormalitas spermatozoa. Pemberian tepung kedelai kaya isoflavon dengan dosis isoflavon tertinggi ( $6 \mathrm{mg} / \mathrm{ekor} / \mathrm{hari}$ ) mengakibatkan kasus infertilitas tikus jantan. Dosis isoflavon $1.5 \mathrm{mg} / \mathrm{ekor} / \mathrm{hari}$ merupakan dosis optimum, mengakibatkan: meningkatnya berat testis, motilitas spermatozoa dan konsentrasi spermatozoa. Kesimpulan: Pemberian tepung kedelai kaya isoflavon pada dosis isoflavon $1.5 \mathrm{mg} / \mathrm{ekor} / \mathrm{hari}$ dapat meningkatkan kualitas spermatozoa tikusjantan. [MKB. 2009;41(4):180-6].
\end{abstract}

Kata kunci: Tepung kedelai kaya isoflavon, kualitas spermatozoa

\section{The Effects of Isoflavone-riched Soybean Flour on The Quality of Spermatozoa of Male Rats}

\begin{abstract}
Reactive oxygen species (ROS) are free radicals that play a significant role in many of the sperm physiological processes. Spermatozoa need low amounts of endogenous ROS to inducing that processes for acquisition of spermfertilizing ability. Isoflavone as the active compound in soybean can act as scavenger free radicals, prevent formation of lipid peroxide, and prevent of oxidative stress condition on the tissue that produce spermatozoa. Twenty five males of Sprague Dawley weaning rats (21 days old) were divided into five groups and treated with isoflavone-riched soybean flour by oral administration with different levels (dosage) for 2 months. Conception rate and the number of fetus were evaluated on the mated-female rats. Diet was given as isonitrogen and isocaloric with $10 \%$ of dietary protein from casein for male and female rats. Result indicated that the treatment didn't affect significantly on spermatozoa abnormality. The treatment of isoflavone-riched soybean flour on male rats with highest dosage (6 mg isoflavone/day) resulted in infertility. The optimum dosage of isoflavone was $1.5 \mathrm{mg} / \mathrm{day}$ and resulted in increase of relative of weight testes, higher motility rate and sperm concentration of rat testes. Conclusion : Isoflavone-riched soybean flour treatment with $1.5 \mathrm{mg}$ /day dosage of isoflavone improved the quality of spermatozoa of male rats. [MKB.2009;41(4):180-6].
\end{abstract}

Key words: Isoflavone-riched soybean flour, quality of spermatozoa

Korespondensi: Dr. Ir. Sussi Astuti, M.Si, Jurusan Teknologi Hasil Pertanian, Fakultas Pertanian Universitas Lampung, Jln. Prof. Sumantri Brojonegoro No. 1 Bandar Lampung, Telp. (0721) 781823, email: irfanaffandi2006@yahoo.com 


\section{Pendahuluan}

Radikal bebas dibentuk oleh metabolisme xenobiotik atau metabolisme sel aerob secara normal. Senyawa spesies oksigen reaktif(Reactive Oxygen Species/ROS) adalah radikal bebas yang punya peran penting pada beberapa proses fisiologis spermatozoa seperti kapasitasi, hiperaktivasi, reaksi akrosom, dan fusi dengan oosit. ' Spermatozoa membutuhkan ROS pada level rendah untuk menginduksi proses kapasitasi dan pada reaksi akrosom, ${ }^{2}$ serta berikatan dengan zona pelusida sehingga dapat berlangsung proses fertilisasi. ${ }^{3}$

Pembentukan ROS menginduksi peroksidasi lipid yang bersifat sitotoksik akibat inisiasi suatu reaksi rantai ke dalam membran, diikuti dengan reaksi propagasi sehingga secara keseluruhan akan mengakibatkan kerusakan sel. Pembentukan ROS yang berlebihan maka akan memicu stres oksidatif, berpotensi mengakibatkan pengaruh toksik, dan merupakan mediator penting terhadap berkurangnya fungsi dan kualitas spermatozoa. Berlebihnya pembentukan ROS dihubungkan dengan penurunan motilitas, morfologi abnormal, dan penurunan kapasitas penetrasi spermatozoa dengan oosit, serta penurunan fertilitas. ${ }^{3,4}$

Spermatozoa memiliki sistem pertahanan enzimatik atau non enzimatik untuk menetralkan pengaruh toksik senyawa ROS pada spermatozoa, sehingga ROS hanya terdapat dalam jumlah kecil yang diperlukan untuk menjaga fungsi spermatozoa tetap normal. Sistempertahanan radikal bebas, baik enzimatik maupun non enzimatik, meliputi proteksi terhadap berbagai kompartemen sel antara lain mitokondria, retikulum endoplasma, peroksisom, sitoplasma dan membran sel. Pemeliharaan integritas sel tergantung pada keseimbangan antara pembentukan radikal bebas dengan sistem pertahanan radikal bebas. Terjadinya kerusakan sel dihasilkan oleh ketidakseimbangan antara pembentukan ROS dan aktivitas pertahanan enzim antioksidan(scavenger).

Terdapatnya radical scavenger diduga akan membersihkan radikal bebas pada jaringanjaringan yang memproduksi spermatozoa. Bahan pangan alami yang mengandung antioksidan, yang berperan sebagai penangkap radikal bebas dapat menekan proses oksidasi, peroksidasi lipid dan kerusakan sel spermatozoa, serta mencegah kondisi stres oksidatif sehingga diduga dapat mengurangi kasus infertilitas. ${ }^{2}$ Di samping itu, konsumsi bahan pangan alami yang mengandung antioksidan dilaporkan juga dapat meningkatkan status antioksidan.

Kacang kedelai dilaporkan memiliki senyawa bioaktif isoflavon (salah satu golongan flavonoid) yang bersifat sebagai antioksidan. ${ }^{5}$ Kacang kedelai dikenal sebagai fitoestrogen karena struktur molekul isoflavon kedelai mirip dengan struktur molekul estrogen. Hal ini menyebabkan isoflavon kedelai dapat berikatan dengan reseptor estrogen (RE), namun afinitas RE ligan tersebut lebih rendah dibanding estrogen endogen sel epitel dari jaringan reproduksi seperti kelenjar susu, ovari dan testis merupakan subyek dari aksi isoflavon. Mekanisme aksi biologis estrogen adalah kemampuannya untuk bertindak sebagai estrogen agonis yang dapat berikatan dengan RE dan menstimulasi respon estrogen, atau bertindak sebagai estrogen antagonis yang dapat berikatan dengan RE namun menghambat respon estrogen. ${ }^{6}$ Isoflavon dilaporkan bersifat antagonis ketika kadar estrogen tinggi, sebaliknya isoflavon bersifat agonis ketika kadar estrogen rendah. ${ }^{\text {? }}$

Penggunaan salah satu produk olahan kacang kedelai sebagai ingredient dalam bentuk kapsul atau tablet adalah tepung kedelai kaya isoflavon. Tepung kedelai kaya isoflavon mengandung kadar isoflavon sebesar 3\%, dihasilkan dari biji kedelai tanpa proses kimia atau penambahan bahan tambahan pangan, serta mempunyai rasa dan aroma yang disukai. ${ }^{8}$

Konsumsi isoflavon pada pria umur 18-46 tahun dengan dosis $40-70 \mathrm{mg} /$ hari dilaporkan tidak akan mempengaruhi kualitas spermatozoa. ${ }^{9}$ Sedangkan pada pemberian genistein (salah satu bentuk isolat isoflavon murni) melalui injeksi pada dosis $4 \mathrm{mg} / \mathrm{kg}$ berat badan/hari dilaporkan menyebabkan perubahan pada berat testis, serta berkurangnya volume lumen pada tubuli seminiferi dan terganggunya spermatogenesis. ${ }^{10}$

Pengaruh isoflavon terhadap fertilitas jantan masih menimbulkan kontroversi, dipandang perlu untuk dilakukan penelitian lebih lanjut. Dalam penelitian ini akan dikaji asupan antioksidan alami (isoflavon) yang terkandung dalam tepung kedelai kaya isoflavon pada berbagai tingkatan dosis terhadap kualitas spermatozoa dengan menggunakan tikus jantan sebagai hewan model.

\section{Metode}

Bahan utama yang digunakan dalam penelitian 
adalah tepung kedelai kaya isoflavon (TKI) dari perusahaan SoyLife Extra ORFFA BELGIUM NV, Ambachtsstraat 6-B-1840 LONDERZEEL. n-heksana digunakan untuk mengurangi lemak pada TKI sehingga diperoleh TKI rendah lemak (TKI-RL). ${ }^{11}$

Tikus jantan dan betina strain Sprague Dawley (SD) umur 21 hari dari PT Indoanilab Bogor digunakan untuk studi in vivo. Bahan penyusun ransum adalah kasein, mineral mix, vitamin mix, minyak jagung, selulosa, air dan pati jagung/ maizena. Pada analisis kualitas spermatozoa menggunakan Natrium Chlorida $(\mathrm{NaCl})$, eosin, nigrosin, giemsa dan metanol. Untuk mengetahui kondisi estrus dan mendeteksi ada tidaknya spermatozoa pada tikus betina digunakan $\mathrm{NaCl}$, alkohol, metanol dan giemsa.

Sebanyak 25 ekor tikus jantan dan 25 ekor tikus betina strain Sprague Dawley umur sapih (21 hari) terlebih dahulu diadaptasikan di lingkungan laboratorium tempat percobaan selama 1 minggu. Ransum yang diberikan pada tikus jantan dan tikus betina merupakan ransum basal kasein yang disusun secara isonitrogen dan isokalori dengan kadar protein ransum sebesar $10 \%$, modifikasi AOAC (1990) $)^{12}$ dan diberikan secara ad libitum. Bahan penyusun ransum tikus jantan adalah kasein, mineral mix, vitamin mix, minyak jagung, selulosa, air dan pati jagung/maizena. Setelah masa adaptasi, tikus jantan dibagi dalam 5 kelompok, yaitu: Kontrol, cekok aquades; cekok TKI-RL dosis isoflavon (IF) $1.5 \mathrm{mg} / \mathrm{ekor} / \mathrm{hari}$; cekok TKI-RL dosis IF $3 \mathrm{mg} / \mathrm{ekor} / \mathrm{hari}$; cekok TKI-RL dosis IF $4.5 \mathrm{mg} / \mathrm{ekor} / \mathrm{hari}$; dan cekok TKI-RL dosis IF $6 \mathrm{mg} / \mathrm{ekor} /$ hari.

TKI-RL diberikan pada tikus jantan dengan cara dicekok menggunakan sonde lambung, dengan melarutkan TKI-RL dalam $1 \mathrm{ml}$ aquades. Perlakuan diberikan selama 2 bulan. Pemberian TKI-RL pada tikus jantan dengan cara in vivo dilakukan berdasarkan pengukuran kandungan total senyawa isoflavon. Hasil analisis dengan High Performance Liquid Chromatography (HPLC) terhadap TKI-RL menunjukkan adanya tiga komponen senyawa isoflavon yaitu daidzein, genistein, dan glisitein dengan kandungan total senyawa isoflavon sebesar $2,22 \mathrm{~g} / 100 \mathrm{~g} \mathrm{bb}$. ${ }^{11}$

Setelah 2 bulan perlakuan, maka tikus jantan digabung dengan tikus betina (1:1). Setiap pagi pada tikus betina dilakukan usap vagina dengan menggunakan teknik pewarnaan giemsa untuk mengetahui kondisi estrus dan mendeteksi ada tidaknya spermatozoa. Setelah terdeteksi adanya spermatozoa pada vagina tikus betina (dihitung sebagai H1 kebuntingan), sedangkan pada tikus jantan dikorbankan dengan dipatahkan tulang leher (dislocasio cervicalis). Bagian testis dikoleksi dan dilakukan pengamatan terhadap berat testis. Kualitas spermatozoa diamati dari bagian cauda epididimis. Pada umur kebuntingan 15 hari (H15), tikus betina dikorbankan untuk pengamatan terhadap angka konsepsi dan jumlah fetus.

Pengukuran berat relatif testis tikus dilakukan terhadap berat badan tikus adalah:

[berat testis (g)/berat badan (g) x 100\%]

Sperma tikus jantan diambil dari bagian kauda epididimis dengan disayat dan dipencet perlahan. Satu tetes sperma ditempatkan pada gelas obyek, ditambah satu tetes larutan $\mathrm{NaCl}$ fisiologis $0.9 \%$, dicampur merata menggunakan satu batang gelas steril, kemudian ditutup gelas penutup. Persentase spermatozoa motil dihitung dalam satu luasan bidang pandang dengan menggunakan mikroskop cahaya pada pembesaran 400x, dengan menaksir spermatozoa yang bergerak progresif dari keseluruhan lapangan pandang dan daerah taksir, lalu dikali $100 \%{ }^{13}$

Perhitungan pada konsentrasi spermatozoa dilakukan dengan slide hemositometer. Caranya, pipet eritrosit diisi dengan sperma yang belum diencerkan sampai tanda 0,5 . Selanjutnya, larutan eosin $0,2 \%$ dihisap sampai tanda 101 pada pipet eritrosit. Campuran dikocok dengan hati-hati tetapi cukup cepat menurut angka 8 selama 2-3 menit. Beberapa tetes dibuang dan dikocok lagi, beberapa tetes dibuang lagi, dan kemudian satu tetes ditempatkan di bawah gelas penutup (slide) hemositometer pada ketebalan $0,1 \mathrm{~mm}$. Kemudian konsentrasi spermatozoa dihitung pada kamar hitung Neubauer.

Sel-sel spermatozoa dalam kamar dihitung menurut arah diagonal (5 kamar). Karena setiap kamar mempunyai 16 ruang kecil, maka dalam kamar terdapat 80 ruang kecil. Seluruh gelas hemositometer memiliki 400 ruangan kecil. Volume setiap ruangan kecil adalah $0,1 \mathrm{~mm}^{3}$. Pengenceran 200 kali $(101 / 0,5)$. Apabila dalam 5 kamar atau 80 ruang kecil kemudian terdapat $Z$ spermatozoa, maka konsentrasi spermatozoa yang diperiksa adalah: $:^{13}$

$$
\begin{aligned}
& Z \times \frac{400}{80} \times 10 \times 200=Z \times 10.000 \\
& =Z \times 0.01 \text { juta spermatozoa } / \mathrm{mm}^{3}
\end{aligned}
$$


$=\mathrm{Z} \times 10^{7}$ spermatozoa $/ \mathrm{mL}$

Satu tetes suspensi sperma dibuat sediaan ulas, dan difiksasi dengan metanol serta diwarnai dengan giemsa. Maka pemeriksaan morfologi abnormalitas spermatozoa dilakukan berdasarkan jumlah spermatozoa normal dan abnormal. ${ }^{13}$

Abnormalitas spermatozoa $=$

$\sum$ spermatozoa abnormal x $100 \%$

$\Sigma$ spermatozoa abnormal + normal

Pengamatan terdeteksinya spermatozoa pada vagina tikus betina dan dihitung sebagai hari pertama kebuntingan untuk melihat terjadinya kopulasi. Pada umur kebuntingan 15 hari (H15), tikus betina dikorbankan. Jumlah tikus betina bunting (dalam persen) dinyatakan sebagai angka kebuntingan (angka konsepsi), serta dilakukan penghitungan terhadap jumlah fetus pada uterus kiri dan kanan.

Data diolah menggunakan uji sidik ragam dengan Rancangan Acak Lengkap (RAL) untuk mengetahui pengaruh perlakuan terhadap parameter yang diuji. Untuk mengetahui perbedaan antar perlakuan, data yang menunjukkan pengaruh nyata selanjutnya diuji dengan Duncan Multiple Range Test (DMRT).

\section{Hasil}

Secara keseluruhan, kualitas spermatozoa akibat perlakuan variasi dosis isoflavon yang meliputi motilitas, konsentrasi, abnormalitas spermatozoa, butiran sitoplasma, serta berat relatif testis tikus jantan tersaji pada Tabel 1, sedangkan angka konsepsi dan jumlah fetus pada tikus betina tersaji pada Tabel 2.

Pada Tabel 1, kelompok TKI-RL dengan dosis IF $1,5 \mathrm{mg} / \mathrm{ekor} /$ hari dapat menghasilkan motilitas spermatozoa, konsentrasi spermatozoa dan berat testis paling tinggi secara nyata $(\mathrm{p}<0,05)$ dibanding kelompok lain. Motilitas spermatozoa kontrol lebih tinggi dibanding kelompok TKI-RL dosis IF $3 \mathrm{mg} /$ ekor/hari, tidak terlihat perbedaan konsentrasi spermatozoa dan berat relatif testis kelompok kontrol dan kelompok TKI-RL dosis IF $3 \mathrm{mg} /$ ekor/hari. Pada kelompok TKI-RL dosis IF 4,5 dan $6 \mathrm{mg} / \mathrm{ekor} /$ hari menghasilkan motilitas spermatozoa, konsentrasi spermatozoa dan berat relatif testis tertinggi secara nyata $(\mathrm{p}<0,05)$ dibanding kelompok lain. Maka tidak terlihat pengaruh nyata antar perlakuan $(\mathrm{p}>0,05)$ terhadap abnormalitas spermatozoa. Kelompok TKI-RL dosis IF $6 \mathrm{mg} / \mathrm{ekor} / \mathrm{hari}$ menghasilkan butiran

Tabel 1 Kualitas Spermatozoa Tikus Setelah 2 Bulan Perlakuan

\begin{tabular}{|c|c|c|c|c|c|}
\hline Perlakuan & $\begin{array}{c}\text { Motilitas } \\
\text { Spermatozoa } \\
(\%)\end{array}$ & $\begin{array}{c}\text { Konsentrasi } \\
\text { Spermatozoa } \\
\text { (juta/mL) }\end{array}$ & $\begin{array}{c}\text { Abnormalitas } \\
\text { Spermatozoa } \\
(\%)\end{array}$ & $\begin{array}{c}\text { Butiran } \\
\text { Sitoplasma } \\
(\%)\end{array}$ & $\begin{array}{c}\text { Berat } \\
\text { Relatif } \\
\text { Testis (\%) } \\
\end{array}$ \\
\hline $\begin{array}{l}\text { Kontrol, cekok } \\
\text { aquades }\end{array}$ & $72,5 \pm 1,77^{\mathrm{c}}$ & $1256,90 \pm 18,53^{b}$ & $9,02 \pm 2,01^{\mathrm{a}}$ & $10,00 \pm 0,83^{\mathrm{a}}$ & $0,5513 \pm 0.02^{b}$ \\
\hline $\begin{array}{l}\text { Isoflavon } 1,5 \\
\mathrm{mg} / \mathrm{ekor} / \mathrm{hari}\end{array}$ & $77,5 \pm 2,50^{\mathrm{d}}$ & $1393,75 \pm 30,62^{c}$ & $8,99 \pm 1,29^{a}$ & $8,92 \pm 1,08^{\mathrm{a}}$ & $0,5894 \pm 0,03^{\mathrm{c}}$ \\
\hline $\begin{array}{l}\text { Isoflavon } 3 \\
\mathrm{mg} / \text { ekor/hari }\end{array}$ & $63,0 \pm 4,11^{\mathrm{b}}$ & $1238,00 \pm 19,72^{b}$ & $9,07 \pm 1,23^{\mathrm{a}}$ & $10,82 \pm 0,64^{\mathrm{a}}$ & $0,5396 \pm 0,02^{b}$ \\
\hline $\begin{array}{l}\text { Isoflavon } 4,5 \\
\mathrm{mg} / \text { ekor/hari }\end{array}$ & $55,0 \pm 3,54^{\mathrm{a}}$ & $1113,75 \pm 31,68^{\mathrm{a}}$ & $10,22 \pm 0,94^{\mathrm{a}}$ & $29,20 \pm 4,82^{b}$ & $0,4925 \pm 0,03^{\mathrm{a}}$ \\
\hline $\begin{array}{l}\text { Isoflavon } 6 \\
\text { mg/ekor/hari }\end{array}$ & $52,0 \pm 2,74^{\mathrm{a}}$ & $1078,88 \pm 45,83^{\mathrm{a}}$ & $10,62 \pm 0,99^{\mathrm{a}}$ & $63,52 \pm 10,07^{\mathrm{c}}$ & $0,4697 \pm 0,04^{\mathrm{a}}$ \\
\hline
\end{tabular}

Keterangan: Angka yang diikuti oleh huruf yang berbeda pada kolom yang sama menunjukkan adanya perbedaan nyata $(p<0,05)$

Tabel 2 Angka Konsepsi dan Jumlah Fetus pada Tikus Betina

\begin{tabular}{lccc}
\hline \multicolumn{1}{c}{ Perlakuan (Jantan) } & $\begin{array}{c}\text { Angka Kopulasi } \\
\text { pada Tikus Betina } \\
(\mathbf{\%})\end{array}$ & $\begin{array}{c}\text { Angka Konsepsi } \\
\text { pada Tikus Betina } \\
(\%)\end{array}$ & $\begin{array}{c}\text { Jumlah Fetus pada Tikus } \\
\text { Betina (n= 5) }\end{array}$ \\
\hline Kontrol, cekok aquades & 100 & 100 & $10,20 \pm 0,84^{\mathrm{a}}$ \\
Isoflavon 1,5 mg/ekor/hari & 100 & 100 & $10,20 \pm 0,45^{\mathrm{a}}$ \\
Isoflavon 3 mg/ekor/hari & 100 & 100 & $9,60 \pm 1,34^{\mathrm{a}}$ \\
Isoflavon 4,5 mg/ekor/hari & 100 & 60 & $5,40 \pm 4,98^{\mathrm{b}}$ \\
Isoflavon 6 mg/ekor/hari & 100 & 0 & $0,00 \pm 0,00^{\mathrm{b}}$ \\
\hline Keterangan:Angka yang diikutioleh huruf yang berbeda pada kolom yang sama menunjukkan adanya perbedaan nyata $(\mathrm{p}<0,05)$
\end{tabular}


sitoplasma paling tinggi secara nyata $(\mathrm{p}<0,05)$ dibanding dengan kelompok lain. Tidak terlihat perbedaan butiran sitoplasma kelompok kontrol dengan kelompok TKI-RL dosis IF 1.5 dan 3 $\mathrm{mg}$ /ekor/hari, namun pada butiran sitoplasma ketiganya lebih rendah dibanding kelompok TKIRL dosis IF 4,5 mg/ekor/hari.

\section{Pembahasan}

Tingginya motilitas spermatozoa, dan konsentrasi spermatozoa serta berat relatif testis pada kelompok yang dicekok TKI-RL dengan dosis IF paling rendah (1.5 mg/ekor/hari) (Tabel 1), diduga dikarenakan isoflavon bersifat antagonis, yaitu menghambat respon estrogen dengan bertindak sebagai antioksidan. Mekanisme isoflavon sebagai antioksidan adalah sebagai donor ion hidrogen dan menangkap radikal bebas (free radical scavenger) secara langsung. ${ }^{5}$ Diduga, membran plasma spermatozoa yang terlindung oleh antioksidan isoflavon mampu mengatur keluar masuk substrat dan elektrolit dengan baik, sehingga proses metabolisme seperti glikolisis dapat berlangsung dengan baik.

Adenosin trifosfat (ATP) yang mengandung energi di hasilkan dari proses metabolime ini, sehingga motilitas spermatozoa dipertahankan tetap tinggi. Sedangkan pada dosis $1.5 \mathrm{mg} / \mathrm{ekor} /$ hari, isoflavon bekerja paling efektif dan optimal, yang mengakibatkan sel testis sebagai organ pembentuk spermatozoa terlindungi dan tidak mengalami kerusakan (tetap utuh), sehingga mampu untuk mempertahankan diri dari serangan oksidatif senyawa radikal bebas. Maka dengan terlindungnya sel testis dari proses oksidasi, diduga proses spermatogenesis tidak terhambat atau terganggu sehingga dihasilkan konsentrasi spermatozoa yang lebih tinggi. Untuk Eliminasi radikal bebas pada jaringan yang memproduksi spermatozoa oleh aksi isoflavon pada dosis tersebut, dan diduga juga dapat menyebabkan perkembangan testis sebagai tempat utama berlangsungnya proses spermatogenesis untuk memproduksi spermatozoa menjadi tidak terhambat.

Motilitas spermatozoa kelompok TKI-RL dosis IF $3 \mathrm{mg} /$ ekor/hari lebih tinggi dibanding kelompok TKI-RL dosis IF 4.5 dan 6 mg/ekor/ hari, namun lebih rendah dibanding kontrol. Diduga, dosis IF $3 \mathrm{mg} / \mathrm{ekor} / \mathrm{hari}$ masih terdapat pada konsentrasi yang tidak terlalu tinggi maka belum memberikan pengaruh negatif berupa gangguan terhadap pergerakan spermatozoa mengingat kelompok TKI-RL dosis IF $3 \mathrm{mg} / \mathrm{ekor} /$ hari menghasilkan motilitas spermatozoa lebih tinggi dari $60 \%$. Namun, motilitas spermatozoa kelompok TKI-RL dosis IF $3 \mathrm{mg} /$ ekor/hari lebih rendah dibanding kontrol yang tidak mendapat perlakuan cekok TKI-RL. Hal ini menunjukkan bahwa kelompok kontrol memberikan motilitas spermatozoa lebih baik dibanding kelompok TKIRL dosis IF 3 mg/ekor/hari. Namun Konsentrasi spermatozoa dan berat relatif testis kelompok yang dicekok TKI-RL dengan dosis IF $3 \mathrm{mg} /$ ekor/hari tidak berbeda dengan kelompok kontrol yang mendapatkan cekok aquades. Hasil ini memperlihatkan, pemberian TKI-RL pada dosis IF $3 \mathrm{mg} / \mathrm{ekor} /$ hari tidak memberikan pengaruh yang berarti terhadap konsentrasi spermatozoa dan perkembangan berat testis, baik pengaruhnya terhadap peningkatan atau penurunan konsentrasi spermatozoa dan berat testis.

Motilitas spermatozoa, konsentrasi spermatozoa dan berat relatif testis paling rendah secara nyata dihasilkan oleh kelompok yang dicekok TKI-RL dengan dosis IF 4,5 dan $6 \mathrm{mg} / \mathrm{ekor} / \mathrm{hari}$. Di kedua dosis tersebut, diduga isoflavon bersifat sebagai estrogen agonis dengan menstimulasi respons estrogen sehingga berpotensi menimbulkan gangguan, mengakibatkan rusaknya struktur membran plasma mitokondria spermatozoa akibat proses oksidasi radikal bebas dan menyebabkan peningkatan peroksidasi lipid. Struktur internal mitokondria yang tidak sempurna sehingga mengakibatkan terganggunya proses metabolisme sel spermatozoa. ${ }^{14}$ Dilaporkan bahwa dengan terbentuknya peroksidasi lipid berhubungan dengan peningkatan pembentukan radikal bebas dan berkorelasi dengan penurunan motilitas spermatozoa, penurunan fosforilasi protein pada aksonem dan berkurangnya ATP intrasel ${ }^{15,16}$ serta mengganggu dan menghambat proses spermatogenesis akibat proses oksidasi pada membran sel testis maka konsentrasi spermatozoa berkurang, bahkan pada kondisi yang ekstrim dilaporkan mengakibatkan kasus infertilitas. ${ }^{3}$

Pemberian isoflavon pada dosis tinggi mengakibatkan terhambatnya berat testis. Penyusutan berat testis telah dilaporkan berhubungan dengan penyusutan dimensi tubuli seminiferi sebagai tempat utama berlangsungnya proses spermatogenesis untuk menghasilkan spermatozoa. ${ }^{17}$ Dalam penelitian ini, membuktikan bahwa pemberian 
tepung kedelai kaya isoflavon dengan dosis isoflavon yang semakin tinggi akan menghambat perkembangan testis dan menyebabkan atropi (pengecilan ukuran) testis dibanding kontrol.

Kisaran abnormalitas spermatozoa akibat perlakuan variasi dosis isoflavon antara 8,99 $10,62 \%$, masih tergolong pada kategori normal. Sebaliknya, tingginya butiran sitoplasma pada kelompok TKI-RL dosis IF 6 mg/ekor/hari diduga berhubungan dengan terhambatnya proses pematangan spermatozoa, sehingga berpengaruh pada kualitas spermatozoa. Proses pematangan spermatozoa yang tidak sempurna diperlihatkan dengan ditemukan butiran sitoplasma dalam jumlah banyak pada semen hasil ejakulat. Di samping itu, sifat estrogen agonis akibat dari pemberian isoflavon pada dosis paling tinggi diduga berpotensi menimbulkan gangguan pada organ reproduksi hewan jantan. Adanya gangguan pada proses spermatogenesis kelompok tersebut diperlihatkan dengan tingginya pembentukan butiran sitoplasma pada bagian distal droplet.

Retensi residu sitoplasma pada spermatozoa berkorelasi positif dengan pembentukan senyawa ROS melalui suatu mekanisme yang diperantarai oleh enzim sitosol glukosa-6-fosfat-dehidrogenase $\left(\mathrm{G}_{6} \mathrm{PD}\right)$. ${ }^{4}$ Apabila aktivitas dari enzim $\mathrm{G}_{6} \mathrm{PD}$ inaktif, maka ketersediaan nikotinamida adenin dinukleotida fosfat (NADPH) untuk produksi energi dalam sel akan berkurang, sehingga menyebabkan berkurangnya pembentukan ATP. Terhambatnya ATP berpotensi meningkatkan proses peroksidasi lipid membran spermatozoa. ${ }^{18}$ Penelitian ini, rendahnya motilitas spermatozoa pada kelompok yang dicekok isoflavon dengan dosis paling tinggi terbukti mengakibatkan penurunan konsentrasi spermatozoa dan berat relatif testis, serta mengakibatkan tingginya pembentukan butiran sitoplasma sehingga secara keseluruhan menyebabkan gangguan terhadap kualitas spermatozoa tikus jantan.

Pada Tabel 2, tikus betina yang dikawinkan dengan tikus jantan kelompok kontrol, serta kelompok yang dicekok TKI-RL pada dosis IF 1.5 dan $3 \mathrm{mg} / \mathrm{ekor} / \mathrm{hari}$ mempunyai angka konsepsi $100 \%$ (5 bunting dari 5 ekor yang dikawinkan). Artinya, pada kelompok betina tersebut telah terdeteksi terjadi kopulasi, dan pengamatan pada kebuntingan menunjukkan hasil positif. Tikus betina yang dikawinkan dengan kelompok TKI$\mathrm{RL}$ dosis IF 4,5 mg/ekor/hari mempunyai angka konsepsi $60 \%$ (tiga bunting dari 5 ekor yang dikawinkan). Sedangkan tikus betina yang dikawinkan dengan kelompok TKI-RL dosis IF 6 $\mathrm{mg} /$ ekor/hari mempunyai angka konsepsi $0 \%$ (tidak terjadi kebuntingan dari 5 ekor yang dikawinkan). Namun perlakuan pada kelima kelompok tikus jantan menghasilkan angka kopulasi pada tikus betina masing-masing sebesar $100 \%$, yang menunjukkan bahwa telah terjadi perkawinan/terdeteksi adanya spermatozoa pada tikus betina melalui metode usap vagina.

Angka konsepsi $0 \%$ pada tikus betina memperlihatkan bahwa pemberian TKI-RL pada dosis IF paling tinggi (6 mg/ekor/hari) menyebabkan gangguan dan hambatan terhadap fertilitas tikus jantan tersebut. Walaupun telah terdeteksi adanya spermatozoa pada tikus betina (terjadi kopulasi), namun tidak terlihat adanya kebuntingan setelah dilakukan pengamatan kebuntingan pada hari ke15 (H15) sejak terdeteksi terjadi kopulasi. Kondisi ini menunjukkan bahwa pemberian TKIRL pada dosis IF paling tinggi (6 mg/ekor/hari) menyebabkan kasus infertilitas pada tikus jantan.

Diduga aksi estrogen agonis pada dosis isoflavon tertinggi (6 mg/ekor/hari) menyebabkan rusaknya struktur membran plasma mitokondria spermatozoa akibat proses oksidasi oleh radikal bebas sehingga menurunkan fungsi dan kualitas spermatozoa. Hal ini didukung dengan data hasil rekapitulasi pada Tabel 1, menunjukkan bahwa kelompok tersebut, terjadi atropi testis sehingga menurunkan produksi spermatozoa; motilitas spermatozoa rendah sehingga mengganggu proses metabolisme spermatozoa akibat menurunnya produksi energi berupa ATP intraseluler dan kerusakan aksonem; konsentrasi spermatozoa rendah diakibatkan dari terhambatnya proses spermatogenesis sehingga mengganggu produksi spermatozoa dan menyebabkan berkurangnya konsentrasi spermatozoa. Adanya gangguan terhadap proses spermatogenesis menyebabkan spermatozoa tidak matang, dan juga terlihat dari tingginya pembentukan butiran sitoplasma di bagian distal droplet, yang mengakibatkan terganggunya mekanisme pelepasan butiran sitoplasma sehingga spermatozoa akan dilepaskan dari epitel sel benih dengan membawa kelebihan residu sitoplasma, dan diduga mengakibatkan spermatozoa yang dilepaskan selama spermiasi menjadi tidak matang atau immature. Fungsi spermatozoa tikus kelompok TKI-RL dosis IF 6 mg/ekor/hari menjadi abnormal dan mengakibatkan tikus jantan menjadi infertil karena tidak 
mampu membuntingi tikus betina. Namun, penurunan kualitas dan fungsi spermatozoa tersebut tidak mengganggu perilaku seksual atau tidak mengganggu libido tikus jantan. Hal ini didukung oleh data angka kopulasi pada tikus betina sebesar $100 \%$.

Kesimpulan penelitian ini adalah pemberian tepung kedelai kaya isoflavon pada berbagai tingkatan dosis terhadap tikus jantan tidak berpengaruh terhadap abnormalitas spermatozoa. Pemberian tepung kedelai kaya isoflavon pada dosis isoflavon $6 \mathrm{mg} / \mathrm{ekor} /$ hari pada tikus jantan menyebabkan kasus infertilitas, namun tidak mempengaruhi libido (angka kopulasi pada tikus betina sebesar $100 \%$, sedangkan angka konsepsi sebesar 0\%). Dosis isoflavon optimum yang menghasilkan kualitas spermatozoa tikus jantan terbaik pada $1,5 \mathrm{mg} / \mathrm{ekor} /$ hari dan mengakibatkan meningkatnya berat testis, motilitas spermatozoa dankonsentrasi spermatozoa,

Penulis mengucapkan terima kasih kepada Direktorat Pembinaan Penelitian dan Pengabdian kepada Masyarakat, Ditjen Pendidikan Tinggi, Departemen Pendidikan Nasional RI atas dana penelitian yang diberikan melalui Program Hibah Bersaing XIV.

\section{Daftar Pustaka}

1. Agarwal A, Prabakaran SA, Said TM. Prevention of oxidative stress injury to sperm. J Androl. 2005;26 (6):654-69.

2. Sikka SC. Role of oxidative stress and antioxidants in andrology and assisted reproductive technology. J Androl. 2004;25(1):5-18.

3. Sanocka D, Kurpisz M. Reactive oxygen Species and sperm cells. Reprod Biol Endocrinol. 2004;2:12.

4. Saleh RA, Agarwal A. Oxidative stress and male infertility: from research bench to clinical practice. J Androl. 2002; 23(6): 737-52.

5. Nijveldt RJ, van Nood E, van Hoorn DEC, Boelens PG, van Norren K, van Leeuwen PAM. Flavonoids: A Review of probable mechanism of action and potential applications. Am J Clin Nutr. 2001;74:418-25.
6. Helferich WG, Allred CD, Ju YoungHwa. Dietary estrogens and antiestrogens. Dalam: Helferich W, Winter CK, penyunting. Food toxicology. Boca Raton: CRC Press, 2001. hlm. 202-38.

7. Robertson KM, O'Donnell L, Simpson ER, Jones MEE. The phenotype of the aromatase knockout mouse reveals dietary phytooestrogens impact significantly on testis function. Endocrinology. 2002;143 (8):2913-21.

8. Indiana Soybean Board. 1998. Isoflavone concentration in soy foods. Tersedia dari: http://www.soyfood.com/ nutrition/Isoflavoneconcentration. html.

9. Mitchell JH, Elizabeth C, Kinnibeurgh D, Provan A, Collins AR, Irvine DS. Effect of a phytoestrogen food supplement on reproductive health in normal males. Clin Sci. 2001;100(6): 613-8.

10. Astuti S. Pengaruh tepung kedelai dan tempe dalam ransum terhadap fertilitas tikus percobaan [Tesis]. Bogor: Program Pascasarjana, Institut Pertanian Bogor; 1999.

11. Atanassova N, McKinnell C, Turner KJ, Walker M, Fisher JS, Morley M, et al. Comparative effects of neonatal exposure of male rats to potent and weak (environmental) estrogens on spermatogenesis at puberty and the relationship of adult testis size and fertility: evidence for stimulatory effect of low estrogen levels. Endocrinology. 2000;141:3898-907.

12. Astuti S, Muchtadi D, Astawan M, Purwantara B, Wresdiyati T. Kadar peroksida lipid dan aktivitas superoksida dismutase (SOD) testis tikus yang diberi tepung kedelai kaya isoflavon, seng $(\mathrm{Zn})$, dan vitamin E. MKB. 2008;40(2):59-66.

13. AOAC. Official methods of analysis of the AOAC. AOAC, Inc. Arlington, Virginia. 1990.

14. Partodihardjo S. 1992. Ilmu reproduksi hewan. Jakarta: Mutiara Sumber Widya; 1992.

15. Iwasaki A, Gagnon C. Formation of reactive oxygen species in spermatozoa of infertile patients. Fertil Steril. 1992;57(2):409-16.

16. Asmarinah. Mutasi gen pada pria infertil dengan astenozoospermia. Andrologi: sesuatu yang hilang dalam kesehatan reproduksi untuk mening-katkan kualitas hidup manusia. Kongres Pandi IX dan Kongres Persandi I. 2005;19-23 April. Jakarta.

17. Fritz WA, Cotroneo MS, Wang J, Eltoum IE, Lamartiniere CA. Dietary diethylstilbestrol but not genistein adversely affects rat testicular development. J Nutr. 2003; 133:2287-93

18. Toelihere MR. 1985. Fisiologi reproduksi pada ternak. Bandung: Angkasa; 1985.

19. Senger PL. Pathway to pregnancy and parturition current conception. Washington State:University, Inc; 1999

20. Tremellen K. Oxidative stress and male infertility-a clinical perspective. Hum Reprod Update. 2008;14(3): 243-58. 